\title{
Mercury exposure in relation to foraging ecology and its impact on the oxidative status of an endangered seabird
}

\author{
CECILIA SOLDATINII ${ }^{1 \sim}$, MANRICO SEBASTIANO $^{2 \sim}$, YURI V. ALBORES-BARAJAS ${ }^{3,4 *}$, HAMADA \\ ABDELGAWAD ${ }^{5}$, PACO BUSTAMANTE ${ }^{6,7}$, DAVID COSTANTINI $^{8}$
}

${ }^{1}$ Centro de Investigación Científica y Educación Superior de Ensenada - Unidad La Paz. Calle Miraflores 334, La Paz, Baja California Sur, 23050, Mexico

${ }^{2}$ Centre d'Etudes Biologiques de Chizé (CEBC), UMR 7372 CNRS- Université La Rochelle, France

${ }^{3}$ CONACYT. Consejo Nacional de Ciencia y Tecnología. Av. Insurgentes Sur 1582, Col. Crédito Constructor. Alcaldía Benito Juárez, C.P. 03940, Mexico City.

${ }^{4}$ Universidad Autónoma de Baja California Sur. Km. 5.5 Carr. 1. La Paz, B.C.S., Mexico

${ }^{5}$ Botany and Microbiology Department, Faculty of Science, Beni-Suef University, Beni-Suef, Egypt

${ }^{6}$ Littoral Environnement et Sociétés, UMR 7266 CNRS-Université La Rochelle, 2 rue Olympe de Gouges, 17000 La Rochelle, France

${ }^{7}$ Institut Universitaire de France (IUF), 1 rue Descartes 75005 Paris, France

${ }^{8}$ Unité Physiologie moléculaire et adaptation (PhyMA), Muséum National d'Histoire Naturelle, CNRS, CP32, 57 rue Cuvier, 75005 Paris, France

\footnotetext{
Joint first authorship

* Corresponding author: Yuri V. Albores-Barajas, Email: yalbores@conacyt.mx
} 
Abstract: Mercury is a natural element extensively found in the Earth's crust, released to the atmosphere and waters by natural processes. Since the industrial revolution, atmospheric deposition of $\mathrm{Hg}$ showed a three-to-five-fold enrichment due to human activities. Marine top predators such as seabirds are recognized valuable bioindicators of ocean health and sensitive victims of $\mathrm{Hg}$ toxic effects. $\mathrm{Hg}$ negatively affects almost any aspect of avian physiology; thus, they prove valuable to study the effect of $\mathrm{Hg}$ exposure in vertebrates. The Black-vented Shearwater is endemic to the North-Eastern Pacific Ocean, where it forages along the Baja California Peninsula during the breeding period. The area has no industrial settlement and is in the southern portion of the California Current System (CCS). After observing possible contamination effects in eggshells, we decided to quantify the exposure of breeding birds to $\mathrm{Hg}$ and test for possible effects on oxidative status of the species. The concentration of $\mathrm{Hg}$ in erythrocytes averaged $1.8 \mu \mathrm{g} / \mathrm{g} \mathrm{dw}$ and varied from 1.4 to $2.4 \mu \mathrm{g} / \mathrm{g} \mathrm{dw}$. Males and females had similar Hg concentrations. The individual trophic level (reflected by $\delta^{15} \mathrm{~N}$ ) did not explain $\mathrm{Hg}$ exposure. In contrast, individuals foraging inshore had higher $\mathrm{Hg}$ concentrations than those foraging more offshore (reflected by $\delta^{13} \mathrm{C}$ ). Shearwaters having higher concentrations of $\mathrm{Hg}$ had lower activity of the antioxidant enzyme glutathione peroxidase and showed lower non-enzymatic antioxidant capacity. Levels of plasma oxidative damage, superoxide dismutase and catalase were not associated with $\mathrm{Hg}$. Our results indicate that (i) the foraging habitat is the factor explaining $\mathrm{Hg}$ exposure and (ii) there is some evidence for potential harmful effects of Hg exposure to this seabird species of conservation concern.

Capsule: The foraging habitat is the factor explaining $\mathrm{Hg}$ exposure in seabirds and we observed potential harmful effects of $\mathrm{Hg}$ exposure to a seabird species of conservation concern.

Keywords: Black-vented shearwater; mercury; stable isotopes; shearwater; Pacific Ocean; Baja California Peninsula 


\section{Introduction}

One of the most toxic elements to human health and wildlife is Mercury $(\mathrm{Hg})$, especially in its methylated form Me-Hg (Eagles-Smith et al., 2018), which accumulates in the tissues of living organisms (Mason et al., 1995). Several studies have reported ecologically relevant concentrations of $\mathrm{Hg}$ in wildlife in North America (Scheuhammer et al., 2016; Weiss-Penzias et al., 2016; Zhang et al., 2016) and, to a lesser extent, in Central and South America (Di Marzio et al., 2019; Sebastiano et al., 2016; Sebastiano et al., 2017a). In Mexico, most studies have focused on the Gulf of California, especially for the high presence of industrial, agricultural, and mining activities (Sánchez-Rodríguez et al., 2001). Recent work on 14 fish taxa from Mexico revealed low $\mathrm{Hg}$ levels; thus, $\mathrm{Hg}$ is not expected to cause health issues to local fisheating birds (Elliott et al., 2015). However, several studies reported the presence of relatively high concentrations of $\mathrm{Hg}$ in aquatic birds from this region (Lerma et al., 2016; Ruelas-Inzunza et al., 2009). To the extent of our knowledge, no studies have to date investigated both the presence and the effect of $\mathrm{Hg}$ exposure on local wildlife. Under the predictions that environmental concentrations of $\mathrm{Hg}$ will rise in coming years and the impact of $\mathrm{Hg}$ exposure is likely to be exacerbate by climate change (Krabbenhoft and Sunderland, 2013; St. Pierre et al., 2018; Stern et al., 2012), it is crucial to investigate the concentration of this ubiquitous element in seabird tissues and to provide early warning of its effects on their health status. Indeed, although the detrimental effects of $\mathrm{Hg}$ exposure in captive birds have long been known, we still have a poor understanding of the effects of sublethal $\mathrm{Hg}$ concentrations on individual health of free-living birds (Whitney and Cristol, 2017), and their consequences at the population level (Goutte et al., 2014a; Goutte et al., 2014b), particularly in bird species of conservation concern (Pacyna et al., 2017; Tsao et al., 2009). 
Seabirds are long-lived top predators of marine food webs, bearing high levels of $\mathrm{Hg}$ (Rowe, 2008); thus they prove valuable to study the effects of $\mathrm{Hg}$ exposure in birds. A recent review pointed out that $\mathrm{Hg}$ might negatively affect almost any aspect of avian physiology (Whitney and Cristol, 2017). However, little work has assessed so far the effects of $\mathrm{Hg}$ on physiological traits of wildlife. One way through which $\mathrm{Hg}$ might impact on organism function is through the increase of molecular oxidative damages and disruption of antioxidant defences (Ercal et al., 2001). Because of its great molecular affinity for thiols and selenium (Ralston and Raymond, 2018), Hg may directly impact on the redox mechanisms involving glutathione (reviewed in Whitney and Cristol, 2017), such as antioxidant enzyme activity of glutathione peroxidase (GPx). Previous work on seabirds has shown that exposure to $\mathrm{Hg}$ might increase oxidative damage to lipids (increased oxidative damage, Costantini et al., 2014; increased antioxidant oxidation and enzymatic antioxidant activity, Kenow et al., 2008), thus oxidative status markers provide a fundamental tool to determine the impact of $\mathrm{Hg}$ on seabirds.

During our long-term monitoring project on the Black-vented shearwater (Puffinus opisthomelas) breeding on Natividad Island, we observed some cases of reproductive failure. Therefore, we hypothesized that the shearwater population might be exposed to $\mathrm{Hg}$ concentrations of concern that may affect their health status.

This study main goal was thus to quantify short-term $\mathrm{Hg}$ exposure using blood samples of adult Black-vented shearwaters during the breeding season. We further assessed the antioxidant status and oxidative damage levels to evaluate whether $\mathrm{Hg}$ impacts on the oxidative status. Finally, using carbon and nitrogen stable isotope ratios $\left(\delta^{13} \mathrm{C}\right.$ and $\delta^{15} \mathrm{~N}$, respectively) as proxies, we determined the main routes of contamination. 


\section{Materials and methods}

\section{Species and study site}

The Black-vented shearwater is a burrow-nesting seabird with nocturnal colony attendance and a single egg clutch. It is endemic to Mexico and distributes along the Pacific coasts of North America, and IUCN (International Union for Conservation of Nature) consider it as near threathned (Birdlife-International, 2016). Generally feeds ashore on the continental shelf in high productivity areas, mainly on anchovies, sardines, and squid (Keitt et al., 2000a). According to the described diet of the species (Keitt et al., 2000b), the Black-vented Shearwater expected isotopic values should be between -20 and $-16 \%$ of $\delta^{13} \mathrm{C}$. The species owns a very restricted area of distribution especially during the breeding season, where $95 \%$ of the global population breeds sympatrically on Natividad Island, Mexico (27 $86^{\prime} 25.59^{\prime \prime} \mathrm{N}$, $115^{\circ} 17^{\prime} 14.18^{\prime \prime}$ W; Figure 1), within the El Vizcaino Biosphere Reserve. Birds arrival to the colony starts in December with prospecting individuals reinforcing pair bonds before egg laying, usually occurring from February through March. Eggs hatch in late April - May and chicks are ready to fledge in July (Keitt et al., 2000a; Keitt et al., 2003). Isla Natividad is of conservation interest, hosting "globally significant populations" of the Black-vented Shearwater, according to the IBA criteria (BirdLife-International, 2010).

\section{Spatial analysis}

Using dataloggers specifically designed for this species (Axy-Trek, Technosmart Europe, Rome, Italy), 11 breeding Black-vented Shearwaters were tagged. Dataloggers were attached to the back feathers of the birds (Tesa ${ }^{\circledR} 4651$, Tesa SE, Hamburg, Germany) using 4 strips of marine tape, weighing a total of $11 \mathrm{~g}$ ( $9 \mathrm{~g}$ of the instrument plus $2 \mathrm{~g}$ of tape; $<5 \%$ of body 
mass). Every night, until the bird returned, the colony was visited, and no gps equiped bird failed to return to its burrow. Data loggers were included in this study to identify foraging areas of males and females during the breeding season. Only three birds of those blood sampled were equipped with dataloggers. We assumed the foraging area of the sampled individuals being the same of the foraging areas used by the tracked ones.

Data and sample collection: As part of the long-term monitoring program of the Black-vented Shearwaters, we captured and ringed adult birds at their nests $(n=20)$ at the end of the incubation period (April). We measured the following traits: right-wing length (to the nearest millimeter using a ruler), length of right tarsus from the middle of midtarsal joint to distal end of tarsus-metatarsus (to the nearest $0.1 \mathrm{~mm}$ with a callipers), head plus bill length, bill length (nearest $0.1 \mathrm{~mm}$ ), and body mass (nearest $0.5 \mathrm{~g}$ using a Pesola spring balance). We collected $100 \mu \mathrm{l}$ of blood from the tarsal vein using heparinized syringes and needles; we stored the samples in a ice refrigerated carrier and transported to the field lab. We centrifuged samples after less than 30 minutes from sampling for 3 minutes at $12000 \mathrm{rpm}$ at room temperature and we stored plasma and erythrocytes in separated tubes at $-20^{\circ} \mathrm{C}$ while on the field and at $-80^{\circ} \mathrm{C}$ in the laboratory. A drop of blood $(5 \mu \mathrm{L})$ was collected on filter paper and stored at -20 ${ }^{\circ} \mathrm{C}$ for molecular sexing using a previous protocol (Albores-Barajas et al., 2010), at Dr Adrian Munguia Vega Lab, La Paz, Baja California Sur.

\section{Oxidative status markers}

The non-enzymatic antioxidant capacity was determined using the Ferric Reducing Ability of Plasma (FRAP) test applied to erythrocytes (i.e., Ferric Reducing Ability of Erythrocytes, FRAE) (Benzie and Strain, 1996); it was expressed as $\mu \mathrm{mol}$ Trolox/g 'relative to the fresh weight). We 
measured three antioxidant enzymes in erythrocytes: $i$ ) the activity of superoxide dismutase (SOD) was determined by measuring the inhibition of nitroblue tetrazolium reduction at $560 \mathrm{~nm}$. It was furtherexpressed as $\mathrm{U} / \mathrm{mg}$ protein per minute; ii) the activity of catalase (CAT) was assayed by monitoring the decomposition rate of $\mathrm{H}_{2} \mathrm{O}_{2}$ at $240 \mathrm{~nm}$ and expressed as $\mu \mathrm{mol}$ $\mathrm{H}_{2} \mathrm{O}_{2} /$ mg protein per minute; and iii) glutathione peroxidase (GPX) activity, determined by a spectrophotometric method and expressed as $\mu \mathrm{mol} \mathrm{NADPH} / \mathrm{mg}$ protein per minute. We also used the Thiobarbituric Acid Reactive Substances (TBARS) assay to quantify plasma lipid peroxidation. Values are expressed as nmol of Malondialdehyde (MDA) equivalents/mL of plasma. We used established protocols for vertebrates to perform all the analyses (Sebastiano et al., 2017b; Sebastiano et al., 2018). Detailed protocols are provided in the supplementary material.

\section{Mercury and stable isotopes}

The analysis of isotopic ratios of carbon $\left({ }^{13} \mathrm{C} /{ }^{12} \mathrm{C}\right.$ or $\left.\delta^{13} \mathrm{C}\right)$ and nitrogen $\left({ }^{15} \mathrm{~N} /{ }^{14} \mathrm{~N}\right.$ or $\left.\delta{ }^{15} \mathrm{~N}\right)$ is a powerful tool to identify the foraging habitat and trophic position of wildlife (Hobson 1999, Maruyama, Yamada et al. 2001, Rubenstein and Hobson 2004). The $\delta^{15} \mathrm{~N}$ increases at each trophic level, with consumers' tissues having values between 3 and 5\%o greater than preys they are synthesised from (DeNiro and Epstein 1978, Hobson and Clark 1992, Bearhop, Waldron et al. 2002). Values of $\delta^{13} \mathrm{C}$ decrease from coastal to oceanic habitats, making them useful proxies for assessing habitat use in marine organisms (France 1995, Hobson, Sease et al. 1997, Newsome, Clementz et al. 2010).

We quantified the total concentration of $\mathrm{Hg}$ and both the stable nitrogen and carbon isotope ratios in freeze-dried erythrocytes following previous protocols (Sebastiano et al. 2017). Briefly, we quantified stable nitrogen and carbon isotopes using an elemental analyzer (Flash 
2000, Thermo Scientific, Milan, Italy) together with an isotope ratio mass spectrometer (Delta V Plus with a Conflo IV interface, Thermo Scientific, Bremen, Germany). Values were expressed in the $\delta$ unit notation as parts per mille (\%o) deviation from standards (Vienna Pee Dee Belemnite for $\delta^{13} \mathrm{C}$ and $\mathrm{N}_{2}$ in air for $\delta^{15} \mathrm{~N}$ ). The analytical imprecisions were $<0.10 \%$ ofor carbon and $<0.15 \%$ for nitrogen. $\mathrm{Hg}$ was measured in erythrocytes (aliquots ranging from 0.9 to $1.4 \mathrm{mg}$ ) using a direct mercury analyser AMA-254 fromAltec. The quality control/quality assessment of $\mathrm{Hg}$ determination was evaluated by the analyses of procedural blanks and of CRM (certified reference material) TORT-3 Lobster Hepatopancreas from the NRC, Canada. CRM were analysed at the beginning, at the end of each analytical cycle and every 10 samples. Certified $\mathrm{Hg}$ concentration of the CRM is $0.292 \pm 0.022 \mu \mathrm{g} / \mathrm{g} \mathrm{dw}$ and the average value $( \pm$ SD) obtained in the present study was $0.285 \pm 0.002 \mu \mathrm{g} / \mathrm{g} \mathrm{dw}(\mathrm{n}=15)$. Thus the recovery of the CRM was $97.7 \pm 0.7 \%$. The limit of quantification limit of the AMA was $0.5 \mathrm{ng}$. We expressed the $\mathrm{Hg}$ concentration as $\mu \mathrm{g} / \mathrm{g} d \mathrm{w}$ (dry weight). Because blood is also measured and reported on a wet-weight basis, the formula blood $(w w)=$ blood $(d w) * 0.21$ can be used to convert dryweight values to wet-weight values (i.e. assuming an average $79 \%$ of moisture) as previously done (Ackerman et al., 2016).

\section{Statistics}

We used the software STATISTICA 10 (Tulsa, OK, USA) to run all statistical analyses. All blood samples were corrected at the same site in a single days, thus these factors were not considered. First, we analysed the foraging ecology of species using data from GPS and isotopes. We used a Bayesian framework to analyse stable isotope data (Jackson et al., 2011). We calculated the standard ellipse area corrected for small sample sizes (SEAc), which contains approximately $95 \%$ of the data within a set of bivariate data, in order to quantify 
niche width and then compare it between sexes. For this, we used the SIBER library for $R$ (Jackson et al., 2011). We performed Spatial analyses using R 3.3.1 (R_Core_Team, 2019). Applicable significance level was set at $\alpha=0.050$ for all the analyses. Second, we ran general linear models including sex, $\delta^{13} \mathrm{C}$ and $\delta^{15} \mathrm{~N}$ as main factors and blood $\mathrm{Hg}$ as dependent variable. General linear models were also run to test the association between blood $\mathrm{Hg}$ and oxidative status markers (all as dependent variables in separate models) while controlling for sex, which was included as a main factor. We ran similar models to test the association between blood $\mathrm{Hg}$ and body mass (dependent variable). In this case, sex was included as a main factor and body size index as a covariate. In so doing, the model calculates the strength and direction of the relationship between $\mathrm{Hg}$ and body mass, whilst controlling for the effect of body size on body mass. Thus, the model normalises the body mass by the variation among individuals in body size, while testing the covariation; this approach is preferable to the use of residuals to estimate body condition index (García-Berthou, 2001; Green, 2001). The index of body size was calculated using the PC1 from a PCA on wing length, tarsus length, beak length, head and beak length and beak width.

\section{Results}

We obtained 11 GPS tracks (four males and seven females) during incubation and chick rearing period. We recorded 1493 dives for males and 1666 for females, respectively allowing us to identify foraging areas used (Figure 1). On the basis of $75 \%$ Kernel Density Estimation of diving points, we identified three core foraging areas: a) in shallow waters ( $<200 \mathrm{~m}$ depth) along the northern coast of El Vizcaino Bay, and at the edge of the continental slope (200 m isobath); b) north from Isla Cedros; and c) south of the colony toward Ulloa Gulf. The 
distribution range of the species during the breeding period is also outlined by the $25 \%$ Kernel Density Estimation in Figure 1. We obtained no significant effect of individual or sex on latitude reached (individual: $F_{1,12}=0.002, P=0.962$; sex: $F_{1,12}=0.033, P=0.858$ ), this let us assume that the distribution obtained is representative of the breeding period.

As expected, the $\delta^{13} \mathrm{C}$ values for the Black-vented Shearwater reflected an average of $18.72 \%$ o $\delta^{13} \mathrm{C}$, ranging from coastal waters with a maximum of $-18.02 \%$ o $\delta^{13} \mathrm{C}$ to more oceanic waters with a minimum of $-19.83 \% \circ \delta^{13} \mathrm{C}$. Trophic niche did not differ significantly between sexes, with females showing a larger range towards oceanic waters than males (female $\mathrm{SEAc}=0.600$; male $\mathrm{SEAc}=0.404$, overlap $=0.278$ ). Neither mean values of oxidative status markers nor their variances differed between males and females (t-test, $p \geq 0.07$; Levene test, $p \geq 0.24)$.

The concentration of total $\mathrm{Hg}$ in erythrocytes (Table 1) averaged $1.84 \pm 0.28 \mu \mathrm{g} / \mathrm{g}$ dry weight, varied from 1.41 to $2.40 \mu \mathrm{g} / \mathrm{g}$ dry weight (corresponding to an average of $0.39 \pm 0.06$, range of $0.30-0.50$ in wet weight). Males and females had similar blood Hg (GLM, $p=0.30)$. The foraging area as estimated by $\delta^{13} \mathrm{C}$ was significantly correlated with blood $\mathrm{Hg}$ : shearwaters fishing closer to the mainland had higher $\mathrm{Hg}$ concentrations than shearwaters fishing offshore (GLM, coeff. estimate \pm se: $0.34 \pm 0.09, p=0.002$, Figure 2 ). In contrast, the trophic level of shearwaters as estimated by $\delta^{15} \mathrm{~N}$ did not correlate significantly with blood $\mathrm{Hg}(\mathrm{GLM}, \mathrm{p}=0.49$, Figure 2).

General linear models showed that sex was never a significant predictor of any oxidative status marker or body condition $(p \geq 0.06)$, thus it was removed in order to improve fitting of the models (based on Akaike Information Criterion) and the analyses were re-run. We found moderate and statistically significant associations between $\mathrm{Hg}$ and both FRAE ( GLM, coeff. estimate \pm se: $-7.75 \pm 3.43, p=0.036$ ) and GPx (GLM, coeff. estimate \pm se: $-0.0003 \pm 0.0001$, 
$p=0.036)$ (Figure 3$)$, while Hg was not associated with TBARS $(p=0.69)$, CAT $(p=0.99)$, SOD $(p=0.71)$ nor with body mass normalized by the covariate body size $(p=0.99)$.

\section{Discussion}

We report in the present study the first record of blood Hg concentrations in an endangered seabird from Baja California Peninsula, Mexico, the Black-vented shearwater. The high interindividual variation in $\mathrm{Hg}$ concentrations was partially explained by the foraging habitat but not by the individual trophic level. Our results also provide the first evidence that $\mathrm{Hg}$ exposure might impact the oxidative status of Black-vented shearwaters during reproduction, one of the critical phases of life-history in birds.

High trophic level predators including large fish and fish-eating wildlife can show toxic concentrations of $\mathrm{Hg}$ in their tissues as a consequence of its biomagnification along food webs (Watras et al., 1998). However, we found no relationship between $\mathrm{Hg}$ levels and the nitrogen stable isotope $\delta^{15} \mathrm{~N}$, indicating that blood $\mathrm{Hg}$ concentration in the present species is not related to the trophic position. On the contrary, $\mathrm{Hg}$ was strongly associated with the carbon stable isotope ratios, suggesting that $\mathrm{Hg}$ concentrations may be driven by the feeding habitat of the species. The wide range in $\delta^{13} \mathrm{C}$ indicates that Black-vented shearwaters forage in diverse feeding habitats during the incubation period. Because the carbon signature is higher in coastal environments, our results suggest that birds bearing higher $\mathrm{Hg}$ levels in their blood are the ones feeding closer to the coast. Considering that turnover time in plasma and cellular component of blood vary from about 3 days to about 30 days, respectively (Hobson and Clark, 1993), we can assume that isotopes and $\mathrm{Hg}$ concentrations obtained from erythrocytes are representative of the breeding period and can be associated to the distribution range. Black- 
vented shearwater core foraging areas lie within the California Current System (Soldatini et al., 2019). Breeding period northern tracks evidence foraging areas in the Vizcaino Bay and along the continental slope while southern tracks are mainly along the continental slope. Although the distance between these two systems is not large, their characteristics may be significantly different. These two systems provide nutrients from different origins in the foraging area of the Black-vented shearwater that we can recognize in $\delta^{13} \mathrm{C}$ differences obtained, representing simultaneously a coastal and oceanic origin for food ingested by shearwaters distributing in a rather reduced area. The inverse correlation of $\mathrm{Hg}$ with $\delta^{13} \mathrm{C}$ suggests that shearwaters feeding in coastal waters are more exposed to $\mathrm{Hg}$, resulting in higher $\mathrm{Hg}$ concentration in their blood. This may be due, for example, to the biomagnification potential of $\mathrm{Hg}$ or to an higher concentration of dissolved $\mathrm{Hg}$ in coastal waters. For instance, oligotrophic conditions associated with low productivity (Chouvelon et al., 2018) and/or simplicity of trophic food webs (Carravieri et al., 2020) largely influence Hg bioaccumulation and biomagnification. Furthermore, mesopelagic zones contain higher mercury and methylmercury concentrations than epipelagic (up to 200 meters in depth) areas (Fitzgerald et al., 2007), resulting in enhanced $\mathrm{Hg}$ concentrations in mesopelagic fish (Blum et al., 2013; Chouvelon et al., 2012; Monteiro et al., 1996). Upwelling waters may thus represent an important source of $\mathrm{Hg}$ to surface waters (Conaway et al., 2009) and seabird feeding in more coastal areas may be more exposed to $\mathrm{Hg}$.

Black-vented shearwaters showed lower concentrations of $\mathrm{Hg}$ than Blue-footed booby Sula nebouxii from the same region (Lerma et al., 2016), and than Caspian terns Sterna caspia and Forster's terns Sterna forsteri from San Francisco Bay (Eagles-Smith et al., 2008), but comparable blood $\mathrm{Hg}$ levels to that of Brown noddy Anous stolidus and Cayenne terns Thalasseus sandvicensis from another region (Sebastiano et al., 2017a). Overall, 
concentrations of $\mathrm{Hg}$ in shearwaters were similar to those reported to induce harmful effects in certain bird species. $\mathrm{Hg}$ might impact on organism function when blood concentration exceed 1.0 Mg/g ww (Ackerman et al., 2016). However, sensitivity to Hg exposure may vary widely among species (Heinz et al., 2009). Some seabird species start to suffer detrimental effect of Hg exposure at very low concentrations (Ackerman et al., 2016), while other species show no apparent adverse effect even when exposed to higher concentrations of $\mathrm{Hg}$ (reviewed in Whitney and Cristol, 2017). This has been related to the protective action of Se against the toxicity of $\mathrm{Hg}$, as shown in three skua species (Carravieri et al., 2017), which by interacting with $\mathrm{Hg}$, may mitigate its toxic effects. More generally, the ratio between Se and $\mathrm{Hg}$ is used as an index to deduce potential toxicity risks (Scheuhammer et al., 2015), thus our results warrant further work to quantify Se levels in our species. While Hg levels in the Blackvented shearwater seem relatively moderated, Gibson et al. (2014) found that even low levels of $\mathrm{Hg}$ in blood altered the expression of oxidative stress-related genes in females Doublecrested Cormorants Phalacrocorax auritus. Furthermore, in the Wandering albatross Diomedea exulans, plasma oxidative damage increased with $\mathrm{Hg}$ contamination of red blood cells in females, but not in males (Costantini et al., 2014), further underlying that sensitivity to $\mathrm{Hg}$ may even vary among co-specific individuals and be exacerbated in females, especially during certain life-history stages as reproduction (Costantini et al., 2014).

Shearwaters exposed to higher $\mathrm{Hg}$ levels showed reduced non-enzymatic antioxidant capacity in erythrocytes and activity of GPx, suggesting that $\mathrm{Hg}$ might have impacted on certain pathways related to oxidative status regulation. Hg may impact on the oxidative status either by depleting antioxidant resources or by increasing production of reactive oxygen species, or both (Stohs and Bagchi, 1995). Because oxidative stress impairs important biological functions, including reproduction, birds with lower antioxidant defences might show a limited 
parental investment in reproduction (Bize et al., 2008). Although all individuals were able of breeding successfully, we cannot rule out that any harmful effects of $\mathrm{Hg}$ might emerge later in life or that more contaminated individuals that failed to breed were not included in the present study. Several studies found negative associations between oxidative stress and reproductive or survival perspectives (reviewed in Costantini, 2014). Biochemical evidences showed that Hg can bind to sulfhydryl groups of thiols, such as glutathione, and to interfere with selenoproteines (i.e. glutathione peroxidase). Previous work found that increasing hepatic concentrations of $\mathrm{Hg}$ were significantly associated with reduced GPx activity in Ruddy ducks Oxyura jamaicensis (Hoffman et al., 1998). Similar results have also been reported in mallards Anas platyrhynchos (Hoffman and Heinz, 1998). Thus, even low concentrations of Hg can cause a disruption of important physiological mechanisms. To conclude, our paper recalls the global focus needed for seabird conservation policies and the past effects of contaminants (Risebrough et al., 1968).

\section{Conclusion}

We found large individual variation in the blood concentration of $\mathrm{Hg}$, which was partially explained by the foraging habitat, but not by the individual trophic level nor its sex. $\mathrm{Hg}$ concentrations may be considered as moderate to high when compared to those detected in other species of seabirds. The significant negative correlations we detected between $\mathrm{Hg}$ and two antioxidant markers indicate that $\mathrm{Hg}$ might have interfered with certain pathways of regulation of oxidative status. Given that worrying conservation status of the Black-vented shearwater, we urge further work to understand whether the potentially negative effects we found may cause long-term effects on fitness traits of individuals exposed to higher $\mathrm{Hg}$ concentrations. 


\section{Acknowledgements}

We are grateful for logistical assistance and hospitality the fishing cooperative Buzos y Pescadores of Natividad Island and Comunidad y Biodiversidad A.C.. We also recognise the Biosphere Reserve of Vizcaino for the open and cooperative approach. We are in debt Martha Patricia Rosas Hernandez for her help and Sandra Mariel Gutierrez Serralde and Maressa Arely Polito Zamarron for helping in the field. We are particularly grateful to Francisco Javier Hernandez Martinez and Maria Eugenia Jimenez Torres for their help in sample transportation. We also thank C. Churlaud and M. Brault-Favrou from the Plateforme Analyses Elémentaires of LIENSs laboratory for their support in Hg analyses and G. Guillou from the Plateforme Analyses Isotopiques of LIENSs laboratory for his help in stable isotope analyses. Thanks are due to the CPER (Contrat de Projet Etat-Région) and the FEDER (Fonds Européen de Développement Régional) for funding the IRMS and the AMA of LIENSs laboratory. The Institut Universitaire de France (IUF) is acknowledged for its support to PB as a Senior Member. Part of this research was funded by Ornis italica and project CICESE 691111.

Ethics statement: National and institutional guidelines for the care and use of animals were followed. Fieldwork was carried out under permits SGPA/DGVS/00321/16, January 2016 and extension SGPA/DGVS/003843/16, April 2016 and renewal SGPA/DGVS/00404/17 January 2017.

Author contributions: C.S, M.S., Y.V.A.B. and D.C. formulated the questions; Y.V.A.B. and C.S. collected data; C.S, M.S., and D.C. analysed the data; M.S. and H.A.E. carried out laboratory analyses on oxidative stress while P.B. carried out laboratory analyses on mercury and stable isotopes; C.S., M.S., and D.C. wrote the paper; P.B. and Y.V.A.B. contributed to specific sections of the paper. 


\section{References}

Ackerman JT, Eagles-Smith CA, Herzog MP, Hartman CA, Peterson SH, Evers DC, et al. Avian mercury exposure and toxicological risk across western North America: A synthesis. Science of The Total Environment 2016; 568: 749-769.

Albores-Barajas YV, Massa B, Griffiths K, Soldatini C. Sexual dichromatism in mediterranean storm-petrels hydrobates pelagicus melitensis. Ardeola 2010; 57: 333-337.

Benzie IF, Strain JJ. The ferric reducing ability of plasma (FRAP) as a measure of "antioxidant power": the FRAP assay. Anal Biochem 1996; 239: 70-6.

BirdLife-International. Marine Important Bird Areas: priority sites for the conservation of biodiversity. Cambridge, UK: BirdLife International, 2010.

Birdlife-International. Puffinus opisthomelas. IUCN Red List of Threatened Species. Version 2016. www.iucnredlist.org, 2016.

Bize P, Devevey G, Monaghan P, Doligez B, Christe P. Fecundity and survival in relation to resistance to oxidative stress in a free-living bird. Ecology 2008; 89: 2584-93.

Blum JD, Popp BN, Drazen JC, Anela Choy C, Johnson MW. Methylmercury production below the mixed layer in the North Pacific Ocean. Nature Geoscience 2013; 6: 879.

Carravieri A, Bustamante P, Labadie P, Budzinski $\mathrm{H}$, Chastel $\mathrm{O}$, Cherel Y. Trace elements and persistent organic pollutants in chicks of 13 seabird species from Antarctica to the subtropics. Environment International 2020; 134: 105225.

Carravieri A, Cherel Y, Brault-Favrou M, Churlaud C, Peluhet L, Labadie P, et al. From Antarctica to the subtropics: Contrasted geographical concentrations of selenium, mercury, and persistent organic pollutants in skua chicks (Catharacta spp.). Environ Pollut 2017; 228: 464-473.

Chouvelon T, Cresson P, Bouchoucha M, Brach-Papa C, Crochet S, Miralles F, et al. Oligotrophy as a major driver of mercury bioaccumulation in medium-to high-trophic level consumers: A marine ecosystem-comparative study. Environmental Pollution 2018; 273: 844-854.

Chouvelon T, Spitz J, Caurant F, Mèndez-Fernandez P, Autier J, Lassus-Débat A, et al. Enhanced bioaccumulation of mercury in deep-sea fauna from the Bay of Biscay (north-east Atlantic) in relation to trophic positions identified by analysis of carbon and nitrogen stable isotopes. Deep Sea Research Part I: Oceanographic Research Papers 2012; 65: 113-124.

Conaway $\mathrm{CH}$, Black FJ, Gault-Ringold $\mathrm{M}$, Pennington JT, Chavez FP, Flegal AR. Dimethylmercury in Coastal Upwelling Waters, Monterey Bay, California. Environmental Science \& Technology 2009; 43: 1305-1309.

Costantini D. Oxidative Stress and Hormesis in Evolutionary Ecology and Physiology. Springer Press 2014.

Costantini D, Meillere A, Carravieri A, Lecomte V, Sorci G, Faivre B, et al. Oxidative stress in relation to reproduction, contaminants, gender and age in a long-lived seabird. Oecologia 2014; 175: 1107-16.

Di Marzio A, Lambertucci SA, Fernandez AJG, Martínez-López E. From Mexico to the Beagle Channel: A review of metal and metalloid pollution studies on wildlife species in Latin America. Environmental Research 2019; 176: 108462. 
Eagles-Smith CA, Ackerman JT, Adelsbach TL, Takekawa JY, Miles AK, Keister RA. Mercury correlations among six tissues for four waterbird species breeding in San Francisco Bay, California, USA. Environmental Toxicology and Chemistry 2008; 27: 2136-2153.

Eagles-Smith CA, Silbergeld EK, Basu N, Bustamante P, Diaz-Barriga F, Hopkins WA, et al. Modulators of mercury risk to wildlife and humans in the context of rapid global change. Ambio 2018; 47: 170-197.

Elliott JE, Kirk DA, Elliott KH, Dorzinsky J, Lee S, Inzunza ER, et al. Mercury in Forage Fish from Mexico and Central America: Implications for Fish-Eating Birds. Archives of Environmental Contamination and Toxicology 2015; 69: 375-389.

Ercal N, Gurer-Orhan H, Aykin-Burns N. Toxic metals and oxidative stress part I: mechanisms involved in metal-induced oxidative damage. Curr Top Med Chem 2001; 1: 529-39.

Fitzgerald WF, Lamborg CH, Hammerschmidt CR. Marine Biogeochemical Cycling of Mercury. Chemical Reviews 2007; 107: 641-662.

García-Berthou E. On the misuse of residuals in ecology: testing regression residuals vs. the analysis of covariance. Journal of Animal Ecology 2001; 70: 708-711.

Gibson LA, Lavoie RA, Bissegger S, Campbell LM, Langlois VS. A positive correlation between mercury and oxidative stress-related gene expression (GPX3 and GSTM3) is measured in female Double-crested Cormorant blood. Ecotoxicology 2014; 23: 1004-1014.

Goutte A, Barbraud C, Meillère A, Carravieri A, Bustamante $P$, Labadie $P$, et al. Demographic consequences of heavy metals and persistent organic pollutants in a vulnerable longlived bird, the wandering albatross. Proceedings of the Royal Society B: Biological Sciences 2014a; 281: 20133313.

Goutte A, Bustamante P, Barbraud C, Delord K, Weimerskirch H, Chastel O. Demographic responses to mercury exposure in two closely related Antarctic top predators. Ecology 2014b; 95: 1075-1086.

Green AJ. Mass/length residuals: Measures of body condition or generators of spurious results? Ecology 2001; 82: 1473-1483.

Heinz GH, Hoffman DJ, Klimstra JD, Stebbins KR, Kondrad SL, Erwin CA. Species Differences in the Sensitivity of Avian Embryos to Methylmercury. Archives of Environmental Contamination and Toxicology 2009; 56: 129-138.

Hobson KA, Clark R. Turnover of $13 \mathrm{C}$ in cellular and plasma fractions of blood: implications for nondestructive sampling in avian dietary studies. The Auk 1993; 110: 638-641.

Hoffman DJ, Heinz GH. Effects of mercury and selenium on glutathione metabolism and oxidative stress in mallard ducks. Environmental Toxicology and Chemistry 1998; 17: 161-166.

Hoffman DJ, Ohlendorf HM, Marn CM, Pendleton GWP. Association of mercury and selenium with altered glutathione metabolism and oxidative stress in diving ducks from the San Francisco bay region, USA. Environmental Toxicology and Chemistry 1998; 17: 167172.

Jackson AL, Inger R, Parnell AC, Bearhop S. Comparing isotopic niche widths among and within communities: SIBER-Stable Isotope Bayesian Ellipses in R. Journal of Animal Ecology 2011; 80: 595-602.

Keitt B, Tershy B, Croll D. Black-vented Shearwater (Puffinus opistomelas). In: Poole A, Gill F, editors. 521. The Birds of North America, Inc., Philadelphia, PA, 2000a, pp. 1-16.

Keitt BS, Croll DA, Tershy BR. Dive depth and diet of the black-vented Shearwater ( Puffinus opisthomelas ). Auk 2000b; 117: 507-510. 
Keitt BS, Tershy BR, Croll DA. Breeding biology and conservation of the Black-vented Shearwater Puffinus opisthomelas. Ibis 2003; 145: 673-680.

Kenow KP, Hoffman DJ, Hines RK, Meyer MW, Bickham JW, Matson CW, et al. Effects of methylmercury exposure on glutathione metabolism, oxidative stress, and chromosomal damage in captive-reared common loon (Gavia immer) chicks. Environmental Pollution 2008; 156: 732-738.

Krabbenhoft DP, Sunderland EM. Global Change and Mercury. Science 2013; 341: 1457-1458. Lerma M, Castillo-Guerrero JA, Ruelas-Inzunza J, Fernández G. Lead, cadmium and mercury in the blood of the blue-footed booby (Sula nebouxii) from the coast of Sinaloa, Gulf of California, Mexico. Marine Pollution Bulletin 2016; 110: 293-298.

Mason RP, Reinfelder JR, Morel FMM. Bioaccumulation of mercury and methylmercury. Water, Air, and Soil Pollution 1995; 80: 915-921.

Monteiro L, Costa V, Furness R, Santos R. Mercury concentrations in prey fish indicate enhanced bioaccumulation in mesopelagic environments. Marine Ecology Progress Series 1996; 141: 21-25.

Pacyna AD, Martínez CZ, Miguélez D, Jiguet F, Polkowska Ż, Wojczulanis-Jakubas K. Mercury contamination, a potential threat to the globally endangered aquatic warbler Acrocephalus paludicola. Environmental Science and Pollution Research 2017; 24: 26478-26484.

R_Core_Team. R: A Language and Environment for Statistical Computing. 2019. R Foundation for Statistical Computing, Vienna, Austria 2019.

Ralston NVC, Raymond $\amalg$. Mercury's neurotoxicity is characterized by its disruption of selenium biochemistry. Biochim Biophys Acta Gen Subj 2018.

Risebrough RW, Herman SG, Peakall DB, Kirven MN. Polychlorinated biphenyls in the global ecosystem. Nature 1968; 220: 1098-1102.

Rowe CL. "The Calamity of So Long Life": Life Histories, Contaminants, and Potential Emerging Threats to Long-lived Vertebrates. BioScience 2008; 58: 623-631.

Ruelas-Inzunza J, Hernandez-Osuna J, Paez-Osuna F. Organic and total mercury in muscle tissue of five aquatic birds with different feeding habits from the SE Gulf of California, Mexico. Chemosphere 2009; 76: 415-418.

Sánchez-Rodríguez I, Huerta-Diaz MA, Choumiline E, Holguín-Quiñones O, Zertuche-González JA. Elemental concentrations in different species of seaweeds from Loreto Bay, Baja California Sur, Mexico: implications for the geochemical control of metals in algal tissue. Environmental Pollution 2001; 114: 145-160.

Scheuhammer A, Basu N, Depew D, Burgess N, Champoux L, Wayland M, et al. Health effects of mercury in fish and wildlife in Canada, 2016, pp. 669-692.

Scheuhammer A, Braune B, Chan HM, Frouin H, Krey A, Letcher R, et al. Recent progress on our understanding of the biological effects of mercury in fish and wildlife in the Canadian Arctic. Science of The Total Environment 2015; 509-510: 91-103.

Sebastiano M, Bustamante P, Costantini D, Eulaers I, Malarvannan G, Mendez-Fernandez P, et al. High levels of mercury and low levels of persistent organic pollutants in a tropical seabird in French Guiana, the Magnificent frigatebird, Fregata magnificens. Environ Pollut 2016; 214: 384-393.

Sebastiano M, Bustamante P, Eulaers I, Malarvannan G, Mendez-Fernandez P, Churlaud C, et al. Trophic ecology drives contaminant concentrations within a tropical seabird community. Environ Pollut 2017a; 227: 183-193. 
Sebastiano M, Eens M, Abd Elgawad H, Thoisy Bd, Lacoste V, Pineau K, et al. Oxidative stress biomarkers are associated with visible clinical signs of a disease in frigatebird nestlings. Scientific Reports 2017b; 7: 1599.

Sebastiano M, Eens M, Messina S, AbdElgawad H, Pineau K, Beemster GTS, et al. Resveratrol supplementation reduces oxidative stress and modulates the immune response in free-living animals during a viral infection. Functional Ecology 2018; 32: 2509-2519.

Soldatini C, Albores-Barajas YV, Ramos-Rodriguez A, Munguia-Vega A, González-Rodríguez E, Catoni $C$, et al. Tracking reveals behavioural coordination driven by environmental constraints in the Black-vented Shearwater Puffinus opisthomelas. Population Ecology 2019; 61: 227-239.

St. Pierre KA, Zolkos S, Shakil S, Tank SE, St. Louis VL, Kokelj SV. Unprecedented Increases in Total and Methyl Mercury Concentrations Downstream of Retrogressive Thaw Slumps in the Western Canadian Arctic. Environmental Science \& Technology 2018; 52: 14099-14109.

Stern GA, Macdonald RW, Outridge PM, Wilson S, Chételat J, Cole A, et al. How does climate change influence arctic mercury? Science of The Total Environment 2012; 414: 22-42.

Stohs SJ, Bagchi D. Oxidative mechanisms in the toxicity of metal ions. Free Radical Biology and Medicine 1995; 18: 321-336.

Tsao D, Miles A, Takekawa J, Woo I. Potential Effects of Mercury on Threatened California Black Rails. Archives of environmental contamination and toxicology 2009; 56: 292301.

Watras CJ, Back RC, Halvorsen S, Hudson RJM, Morrison KA, Wente SP. Bioaccumulation of mercury in pelagic freshwater food webs. Science of The Total Environment 1998; 219: 183-208.

Weiss-Penzias PS, Gay DA, Brigham ME, Parsons MT, Gustin MS, Ter Schure A. Trends in mercury wet deposition and mercury air concentrations across the U.S. and Canada. Sci Total Environ 2016; 568: 546-556.

Whitney M, Cristol D. Impacts of Sublethal Mercury Exposure on Birds: A Detailed Review. 244, 2017.

Zhang Y, Jacob DJ, Horowitz HM, Chen L, Amos HM, Krabbenhoft DP, et al. Observed decrease in atmospheric mercury explained by global decline in anthropogenic emissions. Proceedings of the National Academy of Sciences 2016; 113: 526-531. 
Table 1. Descriptive statistics of $\mathrm{Hg}(\mu \mathrm{g} / \mathrm{g} \mathrm{dw}), \delta^{13} \mathrm{C}$ and $\delta^{15} \mathrm{~N}(\%)$ and markers of oxidative status measured in 20 Black-vented shearwaters.

\begin{tabular}{|l|l|l|l|l|l|}
\hline & Mean & Median & Min. & Max. & Std. Dev. \\
\hline $\mathbf{H g}$ & 1.84 & 1.78 & 1.41 & 2.40 & 0.28 \\
\hline $\boldsymbol{\delta}^{13} \mathbf{C}$ & -18.7 & -18.5 & -19.8 & -18.0 & 0.5 \\
\hline $\boldsymbol{\delta}^{15} \mathbf{N}$ & 15.8 & 15.8 & 15.3 & 16.3 & 0.3 \\
\hline TBARS & 96.9 & 101.2 & 51.9 & 131.5 & 20.4 \\
\hline FRAE & 18.1 & 18.6 & 7.0 & 25.9 & 4.6 \\
\hline SOD & 1.01 & 1.04 & 0.47 & 1.50 & 0.22 \\
\hline GPX & 0.0007 & 0.0007 & 0.0005 & 0.0012 & 0.0002 \\
\hline CAT & 0.61 & 0.66 & 0.15 & 0.89 & 0.23 \\
\hline
\end{tabular}




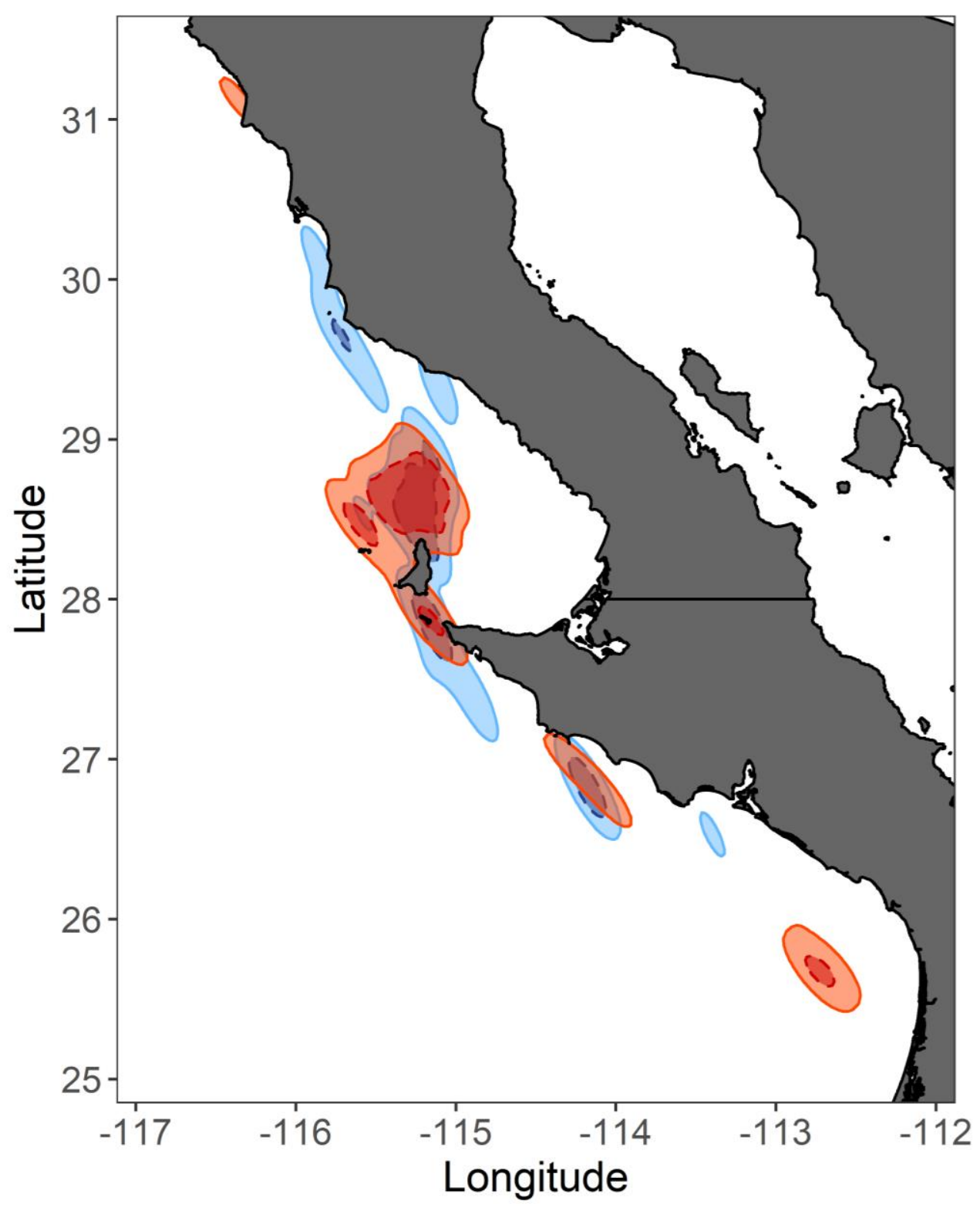

Figure 1. Foraging areas of males (light blue identifying $25 \%$ Kernels and dark blue identifying 75\% Kernels) and females (orange identifying 25\% Kernels and red identifying $75 \%$ Kernels) according to tracks obtained during the breeding period. 


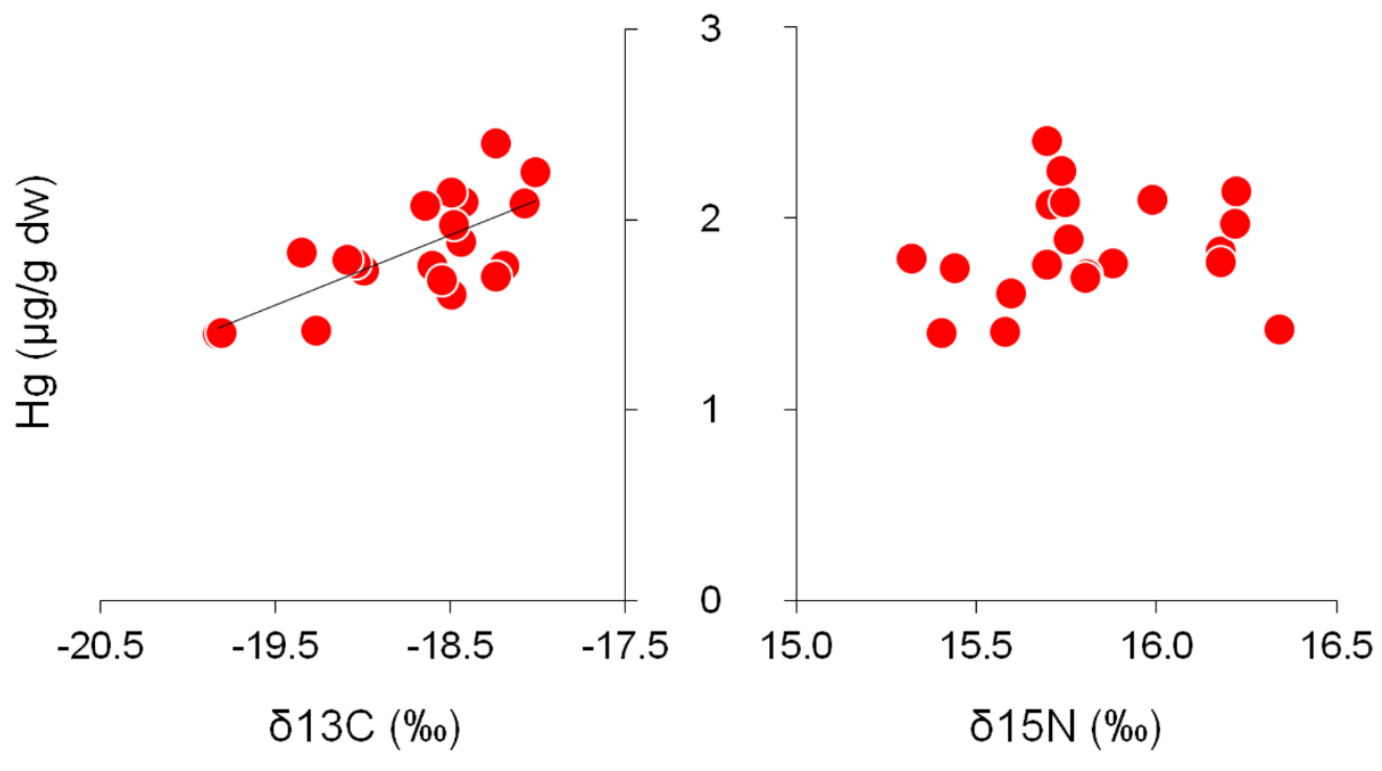

Figure 2. Relationships between blood mercury concentrations ( $\mu \mathrm{g} / \mathrm{g}$ dry weight) and the stable isotope ratios $\delta^{13} \mathrm{C}$ and $\delta^{15} \mathrm{~N}(\%)$. The foraging area as estimated by $\delta^{13} \mathrm{C}$ was significantly correlated with the blood concentration of $\mathrm{Hg}$, while the trophic level of shearwaters as estimated by $\delta^{15} \mathrm{~N}$ did not correlate significantly with blood $\mathrm{Hg}$. 

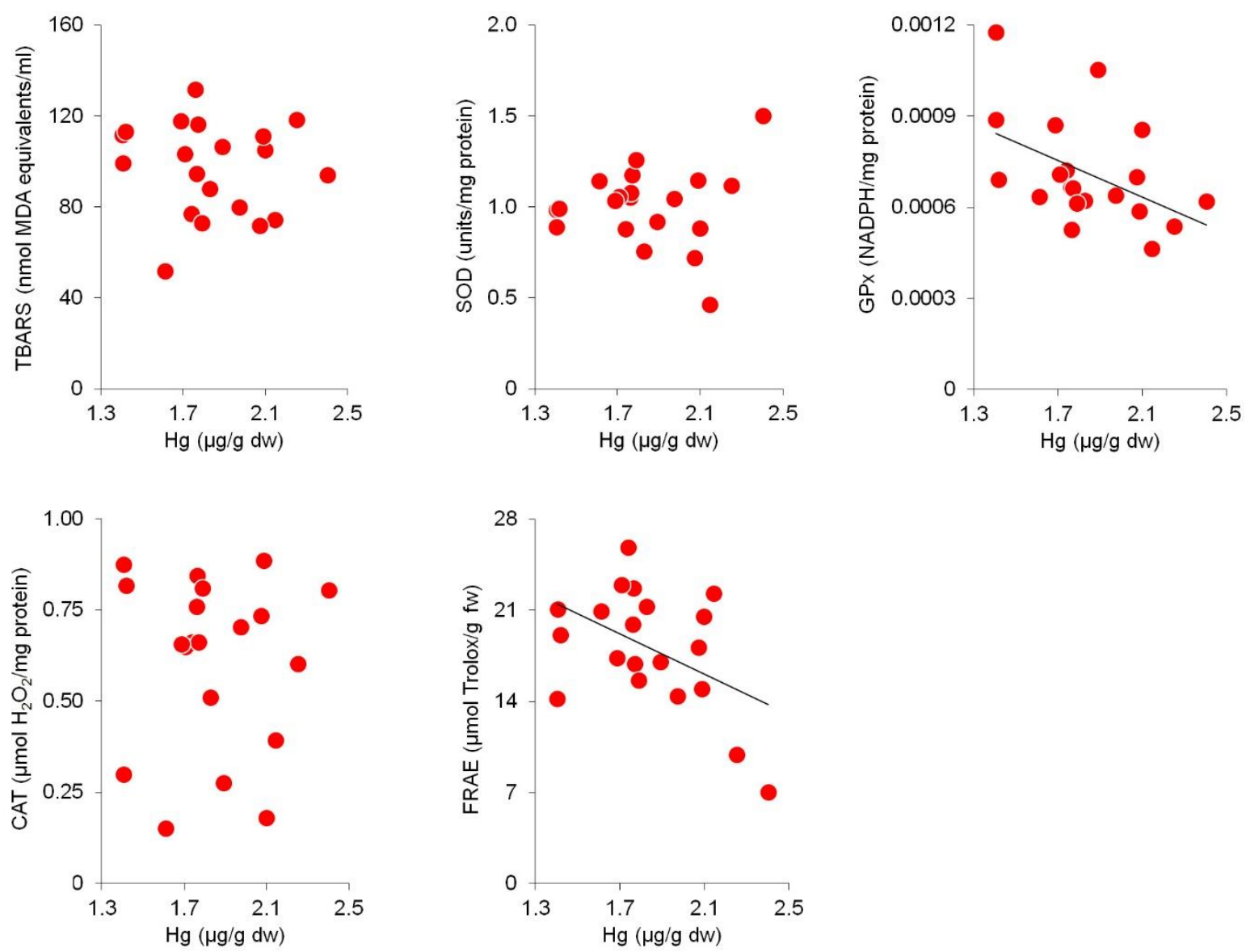

Figure 3. Relationships among blood $\mathrm{Hg}$ ( $\mu \mathrm{g} / \mathrm{g}$ dry weight) and blood-based oxidative status markers. The regression line is reported only when the relationship was statistically significant. TBARS $=$ Thiobarbituric Acid Reactive Substances, $\mathrm{MDA}=$ malondialdeyde, $\mathrm{SOD}=$ superoxide dismutase, $\mathrm{GPx}=$ glutathione peroxidase, $\mathrm{CAT}=$ catalase, $\mathrm{FRAE}=$ Ferric Reducing Ability of Erythrocytes. 


\section{SUPPLEMENTARY MATERIAL}

\section{Blood-based markers of oxidative status}

Non Enzymatic antioxidant power of erythrocytes

The non-enzymatic antioxidant power of erythrocytes was estimated using the FRAP test (1). Briefly, the FRAP reagent was mixed with homogenized red blood cells (about $10 \mu \mathrm{L}$, weighted to the nearest $0.0001 \mathrm{~g}$ ) and the absorption was measured after 30 minutes at $600 \mathrm{~nm}$. The Trolox (6-Hydroxy-2,5,7,8tetramethylchroman-2-carboxylic acid) was used to make a calibration curve. FRAP values were expressed as $\mu \mathrm{mol}$ Trolox/g of fresh weight.

\section{Enzymatic activity}

The activity of antioxidant enzymes, superoxide dismutase (SOD), catalase (CAT) and glutathione peroxidase (GPX) was determined in haemolysates. Red blood cells $(20 \mu \mathrm{L})$ were mixed with $500 \mu \mathrm{L}$ of phosphate buffer ( $\mathrm{pH} 7.4 ; 80.2 \mathrm{~mL}$ of 1M Dipotassium phosphate (K2HPO4) with $19.8 \mathrm{~mL}$ of $1 \mathrm{M}$ Potassium dihydrogen phosphate (KH2PO4)). After vortexing for 30 s, tubes were rapidly put in liquid nitrogen and were then sonicated twice for $30 \mathrm{~s}$ in ice. Samples were then magnalysed for $15 \mathrm{~s}$ at $6500 \mathrm{~g}$ for three times and then centrifuged at $10000 \mathrm{~g}$ for $30 \mathrm{~min}$ in a cold centrifuge (4 degrees). The supernatant $(20 \mu \mathrm{L})$ was then transferred in a plate in duplicate. Superoxide dismutase (SOD) activity was determined by measuring the inhibition of nitroblue tetrazolium (NBT) reduction at $560 \mathrm{~nm}$ and was expressed as $\mathrm{U} / \mathrm{mg}$ protein per minute (2). Catalase activity (CAT) was assayed in red blood cells by monitoring the rate of decomposition of $\mathrm{H} 2 \mathrm{O} 2$ at $240 \mathrm{~nm}$ and was expressed as $\mu \mathrm{mol} \mathrm{H} 2 \mathrm{O} 2 / \mathrm{mg}$ protein per minute (3). Glutathione peroxidase (GPX) activity was measured in red blood cells by measuring the decrease of nicotinamide adenine dinucleotide phosphate (NADPH) absorbance at $340 \mathrm{~nm}$ and was expressed as $\mu \mathrm{mol} \mathrm{NADPH} / \mathrm{mg}$ protein per minute (4).

\section{Oxidative damage to lipids}

Plasma lipid peroxidation was quantified using the Thiobarbituric Acid Reactive Substances (TBARS) assay. Samples ( $5 \mu \mathrm{L}$ of plasma) were mixed with $0.5 \mathrm{~mL}$ of TBA reagent $(0.5 \%(\mathrm{w} / \mathrm{v})$ thiobarbituric acid (TBA) in $20 \%$ TCA), vortexed for 30 s and incubated at $90^{\circ} \mathrm{C}$ for 45 minutes. After incubation, samples were cooled in a bath of ice to stop the reaction. Samples were then centrifuged at 5000rpm for $1 \mathrm{~min}$ and the supernatant was transferred in a plate in duplicate. Absorbance was measured at 532, 600 and 
$450 \mathrm{~nm}$ and the amount of MDA equivalents was calculated using the formula $6.45 *(A 532-\mathrm{A} 600)$ $0.56 * A 450$. Values were expressed as nmol MDA equivalents $/ \mathrm{mL}$ of plasma (5).

\section{References}

1. Benzie IFF \& Strain JJ (1996) The Ferric Reducing Ability of Plasma (FRAP) as a Measure of "Antioxidant Power": The FRAP Assay. Analytical Biochemistry 239(1):70-76.

2. Dhindsa RS, Plumb-Dhindsa P, \& Thorpe TA (1981) Leaf Senescence: Correlated with Increased Levels of Membrane Permeability and Lipid Peroxidation, and Decreased Levels of Superoxide Dismutase and Catalase. Journal of Experimental Botany 32(1):93-101.

3. Aebi H (1984) Catalase in vitro. Methods in enzymology 105:121-126.

4. Drotar A, Phelps P, \& Fall R (1985) Evidence for glutathione peroxidase activities in cultured plant cells. Plant Science 42(1):35-40.

5. Hodges MD, DeLong MJ, Forney FC, \& Prange KR (1999) Improving the thiobarbituric acidreactive-substances assay for estimating lipid peroxidation in plant tissues containing anthocyanin and other interfering compounds. Planta 207(4):604-611. 